University of Nebraska - Lincoln

DigitalCommons@University of Nebraska - Lincoln

To Improve the Academy

Professional and Organizational Development

Network in Higher Education

1998

Divining the Future for Faculty Development: Five Hopeful Signs and One Caveat

Marilla D. Svinicki

Follow this and additional works at: https://digitalcommons.unl.edu/podimproveacad

Part of the Higher Education Administration Commons

Svinicki, Marilla D., "Divining the Future for Faculty Development: Five Hopeful Signs and One Caveat" (1998). To Improve the Academy. 418.

https://digitalcommons.unl.edu/podimproveacad/418

This Article is brought to you for free and open access by the Professional and Organizational Development Network in Higher Education at DigitalCommons@University of Nebraska - Lincoln. It has been accepted for inclusion in To Improve the Academy by an authorized administrator of DigitalCommons@University of Nebraska - Lincoln. 
Svinicki, M. (1998). Divining the future for faculty development: Five hopeful signs and one caveat. In M. Kaplan (Ed.), To Improve the Academy, Vol. 17, (pp. 3-14). Stillwater, OK: New Forums Press and the Professional and Organizational Development Network in Higher Education. Key Words: faculty development, faculty developer role, higher education environment, organizational climate, organizational development.

\section{Divining the Future for Faculty Development: Five Hopeful Signs and One Caveat}

\section{Marilla D. Svinicki}

The University of Texas at Austin

The fortunes of faculty development centers rise and fall on the waves of change that roll through postsecondary education on a regular basis. These waves can swamp us, or we can ride their crest. This article points out some of the waves the author sees now and in the immediate future and how we can benefit from them. She ends with a caution about improving our chances of survival through our own efforts rather than waiting for someone else to draw us along.

When I was asked to do a keynote address on the future of faculty development recently, my instructions were very specific. I was to be inspirational, yet humorous; philosophical yet pragmatic; general, yet specific. Six months before that I might have been a little less enthusiastic about trying to be inspirational about faculty development because I was myself not feeling very inspired. But some interesting developments have since given me much more reason to be hopeful. 
I'd like discuss these developments as a series of answers and questions, along the lines of Johnny Carson's "Carnack the Magnificent." In each case I'll give the answer first and then the question to which the statement is the answer. (You can feel free to imagine me in an appropriately gaudy turban with an envelope to my forehead.)

Answer number one: "Technology, technology, technology."

And the question is: "What is the worst thing to happen to faculty development, the best thing to happen to faculty development, and the only word which, when added to the title of a workshop, will draw faculty like flies to honey?"

I have to admit that I've come close to hearing all I want to hear about how technology is the future of higher education. It seems like everytime we take a poll of what faculty are interested in, technology comes out on top, even though we just did that workshop last semester. I don't think that technology is the answer to all our problems. But I can't deny that it may be one of the answers.

Even in my own undergraduate class, technology seems to be making a difference. During a recent semester, my undergraduate class was doing particularly well on all the exams, even though I had not changed their difficulty level. When I asked them what was so helpful, one of the things they listed was the class website. This was not a fancy site with lots of animated dancing clowns or bells and whistles. All it had on it was the lecture overheads and the in-class activities with an accompanying explanation. They'd seen both of those things before in class, so the psychologist in me said what could possibly be making a difference? Then the pragmatist in me replied that maybe it was making the effort to log on to the Web and call up the site that was forcing them to be a little bit more volitional in their approach to studying. Instead of passively staring at the textbook, they had to $\log$ on and download.

Another effect that technology is having is not so much on the students as on the instructors. It is very possible that the reason computer-based instruction makes a difference in learning is because this is the first time that some faculty have actually thought about the organization of their course and content. They can no longer depend 
on their charm and quick wits to respond in real time to students' needs.

Here is where the boon for faculty development lies: for the first time, faculty feel that it is acceptable to admit that they don't know everything there is to know about instructional design. Instead, they are willing to look around for someone who is willing to help them master the intricacies of this new teaching tool. That someone should be us.

All the skills we have to offer about goal setting, instructional materials design, student learning assessment, and guidance mesh very nicely with the design of technology-based instruction. And sometimes the guidance we have to offer takes the form of advising the faculty member NOT to use the technology, that it is not worth the effort in a given case.

What does this mean for our own development as developers? It means that we cannot let this golden opportunity pass. We must become proficient enough or knowledgeable enough about these new technologies that we can serve an advisory function to faculty. Not every faculty member is going to be interested in asking for help, but they are only too happy to have someone who can translate from computer-ese into English and back.

Although I am still just an amateur myself, I determined that I had to be able to speak knowledgeably about the technology and its relationship to teaching. In addition, I had to get some firsthand experience with it, and hence, the development of the website for my classes. Even though the site is very plain, I was amazed when a faculty member raved about how wonderful my site was and how it had inspired him to do one for his class. Now I am in a position to help him because I've done it myself. And he is much more likely to come to me in the future with other questions now that the ice has been broken.

So the message of this first revelation is that one really good way of reaching faculty is to become their eyes, ears, and hands about the upcoming developments in teaching and learning. They all admit that they don't have the time or the inclination to be constantly up-to-date on new developments, but they would be willing to listen to someone who can talk convincingly about them. That someone should be us. 
Let's move along to the next answer and question.

Answer number two: "Only diamonds are forever."

And the question is: "What does the administration mean when it says 'Post-Tenure Review'?”

Yes, it is true. Even the University of Texas has succumbed to the pressure and instituted a policy about post-tenure review (Magner, 1996). It doesn't exactly say what will happen as a function of post-tenure review, but can that be far behind? Once again we have the opportunity to use what could be a difficult situation to our advantage. The imposition of post-tenure review has put two powerful constituencies of the university in difficult positions.

The deans and department chairs are in a difficult position because they are responsible for seeing to it that post-tenure reviews get carried out in a reasonable manner. The faculty are in a difficult position, especially the senior faculty, because the rules have changed in mid-game, and they must respond to this change.

Some have chosen to fight the idea of post-tenure review, either directly by challenging its legitimacy or indirectly by making it into a sham procedure or denigrating it as an ill-conceived, ill-designed solution to a non-problem. However, both of those approaches are short-sighted. I much prefer the position that the Dean of the Graduate School at UT took at a public forum last year. She said that rather than being afraid of the process or arguing about why we shouldn't submit to it, we should embrace it as a way to show the legislature what a truly remarkable place the university is. She is convinced that on any reasonable measure we will be vindicated in our claims of excellence (Sullivan, 1997).

This is again where faculty development comes into the picture. We have two important groups at the university who need help. Who is better equipped to help them than we are? I welcome the chance to help the administration design a reasonable review system. Better that we should design it than someone in the legislature who has no conception of what it means to be a functioning faculty member.

We have an obligation to learn as much as we can about the review process, so that we can become invaluable advisors to the administra- 
tors who are trying to put a good system into place, one that will respect the strengths of the institution while at the same time being a legitimate measure of what we do. They could only be grateful for the help, and they might come to see us as the valuable resource we can be.

Then there are the faculty, many of them already tenured, who in the past have not felt a need for any outside support. Now they are facing a potentially difficult and anxiety producing task of preparing for a review. And there we are, ready to help them. Not the teaching police, but the emergency rescue team, fully equipped with resuscitators for a wheezing career and uppers for a flagging spirit. If not that, at least a form of verbal Prozac to help them calm down and look on the positive side of the process. And there is a positive side, but it requires re-visioning yourself as a teacher. It requires rekindling faculty interest in the scholarly, problem-solving side of teaching, the thing that really makes it challenging: the opportunity to begin growing again as a reflective practitioner.

I believe that if we are there to help the faculty through this new phase of their careers, they will find our support valuable enough to continue seeking it even after the review process is over. We will finally have an entre into their lives.

What does this mean for us? First, we should become familiar with the processes and concerns of post-tenure review. There has been enough written about it in the national higher education literature over the last few years (see Academe, the 1997 May-June issue, for example). It is unlikely that the administrators or faculty have been able or willing to stay abreast of the national discussion, but they are willing to listen to a synopsis of it if we're ready to provide it. This is our chance. If we know what some of the benefits and pitfalls are (and we may be the only ones who do), we can have a big impact on the eventual form the system will take. At the same time we will win the gratitude of every busy administrator, who knows that something has to be done but is in the midst of twelve other things that have to be done at the same time and at least two of them usually have something to do with lawyers, the student newspaper, or both.

We must be ready to support those faculty who come asking for ideas. Much as we'd like to say "I told you so," we need to rise above such petty thoughts and instead pitch in to help that faculty member 
through the review process. We need to arm ourselves with information about the process, about alternative evaluation strategies, about how to put the gathered information to good use for the faculty's benefit. By turning the process into a positive growth experience, we might just get some of those faculty to recognize the value of regular interactions with the faculty development office.

Answer number three: "MDs and PhDs."

And the question is: "Who make respectively the worst patients and the worst students?"

Do you find that when you set up a workshop all the faculty sit at the back of the room just like the students? Do they demand to know what will be on the test, or in their case, the evaluation of teaching form? Do they forget to bring a pen, paper to the workshop? Do they fail to read the assignment before the seminar?

I don't know why it should come as such a big shock to us. After all they are human beings just like the students. Why should they be any less subject to the laws of behavior than students?

Faculty respond to the pressures of life just the way the students do. If we know a lot about teaching students, why don't we apply that knowledge to working with faculty? For example, we preach that students have a range of learning styles and should have a variety of learning venues available to them, but what do we do with faculty? Workshops and seminars. We know perfectly well that the workshop format is not appropriate for everyone on the faculty. Some people like to learn in private. Can't we think of a way of providing that alternative format for those folks?

We also know, or at least espouse, that active learning is an important component of learning, and yet what do we frequently use in faculty development programs? Lecturing! I had a very interesting experience along those lines once. I received a call from an institution that shall remain nameless asking me to come to their campus and do something on active learning. I said, "Sure, I can do that. What did you have in mind?" And the person on the other end said in all innocence, "Well, we thought maybe you could give an after lunch talk for about 40 minutes." My response, of course, was, "Do you see 
anything wrong with this picture?" There was a long pause and the person said, "Oh, yes, well, I guess that does seem a bit inconsistent, doesn't it?" Nevertheless when I went out to the institution, active learning lecture in hand, I met the same kind of resistance from those faculty that we get from our students: they expected to be lectured to and, by golly, they weren't going to let me get away with making them work.

As a psychologist, I see so much of the field that manifests itself in the actions of faculty. For example, when faculty are entering a new field or skill area, they become just as concrete in their thinking as children who are first going through cognitive development. They ask things like, "Well, how am I going to use that in my class?" "I want an example from my own field." "Just tell me how to do it (which is the faculty equivalent of 'Just tell me what you want on the test')."

The issue here is that our understanding of human behavior has come a long way since the old days. We actually know something about how learning occurs and how to enhance the motivational properties of a situation (Svinicki, Hagen, \& Meyer, 1996; Halpern \& Associates, 1994). But for some reason, we forget to apply those principles to the faculty themselves. Or maybe we never took the trouble to learn them in the first place, and we're flying our faculty development program by the seat of our pants just like the faculty who teach their courses without ever learning anything about their students.

Here is a great opportunity to develop ourselves and our programs. If we take the time to analyze our programs and practices the way we would design a course, maybe we would have a better chance of reaching the learning objectives we have for the faculty. If we don't start putting into practice what we preach to them as good instruction, they won't have much faith in what we say. Most of my undergraduate classes are made up predominantly of aspiring teachers. I know that they are paying attention to much more than my words: they are watching my behavior as well. I'd better be a good practitioner of the craft of teaching, if I'm going to influence their behavior.

The same is true of faculty developers. We have to be good role models at multiple levels of analysis. We need to know at a deep level what it takes to help people learn, and then we need to use that knowledge when we work with the faculty as well. It's tricky to think 
about faculty as learners. It puts them in a whole different light, but it's very instructive as well. On another level, we should also think of ourselves as learners. Why shouldn't we apply the same sort of self-regulated learning strategies to our own development as we would recommend to students? It is a matter of becoming reflective practitioners of our craft. We can hardly argue with that as a good goal.

Now, back to the answers.

The fourth answer: "Today's administrators."

The question is: "Who used to be the scruffy graduate students of the 60s and 70s?"

This revelation came to me recently when I was invited to do a keynote for the Council of Independent Colleges Deans' Institute. These were the important people who make the decisions that affect faculty lives and, in turn, the fortunes of faculty developers.

Prior to this I had been in the habit of thinking of the administration as those old guys who were too stuffy and set in their Byzantine ways to see what a good thing we younger folks had to offer. Then I looked out over the audience and found it was made up of people who looked just like me. So I thought about it for a while and realized that my cohort was now in power! In fact, one of us is actually the President of the United States.

It is kind of a scary thought to imagine all those former idealists controlling budgets and policies now. On the other hand, a great many of us have not lost the idealism that caused us to man the barricades and lobby for change back in the old days. That gives me a lot of hope for higher education and faculty development.

We really were commited to changing the system back then. We could be swayed by arguments about what was the right thing to do. We haven't changed all that much. Now we might be a little less prone to toss caution aside and tear down the existing edifice, but what we lack in impulsivity we make up for in political savvy and clout.

If it truly is people like me who are in administrative positions and can actually do something about conditions beyond holding a sit-in at the administration building (which is essentially what we do on a day-to-day basis anyway, so it wouldn't have much publicity value), 
then maybe we CAN do something to make higher education better.

That's good news for faculty development. We are no longer speaking to an unresponsive audience; now we are talking to folks who felt higher education should have been changed long ago. I saw that kind of response at the Deans' Institute I mentioned earlier. Here were all these academic deans, people who could really do something to make a difference, and they were listening and chiming in and getting kind of enthusiastic about what I had to say about putting learning first. In fact, they were actually complaining to me about the faculty dragging their feet on academic reform.

My advice to faculty developers is to start looking on these adminsitrators as allies in the good fight. They may have been there first long ago, and maybe they're just itching for a chance to make a difference. Support their efforts and you may find that you're all aiming at the same goal: a better future for your institution.

And now for the next answer: "The faculty of tomorrow."

And the question is: "Who are the scruffy graduate students of the 90s?"

Oh no! Not another generation of idealists. Yes, indeed, they're coming! It is my great privilege to teach classes every year for the graduate students at UT who are aspiring to faculty careers. Last summer I had a class of about 24 students from across the university. I team taught it with the Graduate Dean (another former scruffy graduate student idealist, by the way), and it was probably one of the most renewing experiences I have had in a long time.

There were these 24 bright, eager, and determined graduate students, who were spending their time and their money on a course to prepare for their future as teachers, and, believe me, they knew that they wanted that preparation as teachers, not as researchers only. It may be a biased sample, but I think it's far more common than you think.

The importance for faculty developers of this phenomenon is two fold. First, a lot more institutions involved in graduate preparation are recognizing that their students need some preparation in teaching if 
they are to be marketable in the future (Lambert and Tice, 1996). That means for those of us at research institutions that we are getting a lot more support around the issue of preparing graduate students to teach. Graduate deans and advisors are supporting our programs, which means that our students will be coming out of their programs with a much better idea of what it takes to teach. And they will have an accompanying attitude about the value of faculty developers, who, when they were lowly graduate students, took the time to provide them with the attention and skills they needed to succeed. So when they actually join the faculty ranks, they will be more likely to continue that drive to learn about teaching.

And second, for those of you who are at liberal arts colleges, you may see that the new faculty will be coming in with a whole new set of skills and attitudes about teaching that are much more in line with a well-rounded approach. The more you can help those of us at graduate institutions by looking for that kind of quality in advertising and hiring, the sooner we will all get to that day.

One last implication about this potential change in graduate students and new faculty. If you have a limited amount of time, energy, and resources available to your program, let me urge you to consider putting those resources where they're likely to do some good: put them in programs to encourage graduate students and new faculty to become reflective practitioners of teaching. Many programs of this type have been discussed at the six national conferences on graduate student preparation for teaching (Chism, 1987; Nyquist, Wolff, \& Abbot, 1990; Lewis, 1993) and in research on the development of new faculty (Brookfield, 1995; Boice, 1992; Sorcinelli \& Austin, 1992). For example, at the University of Pittsburgh, graduate students and new faculty are encouraged to use some of the Classroom Assessment Techniques introduced by Angelo and Cross (1997). The result is that these individuals become much more conscious of why they make the choices they do (Richlin, 1998). I believe the investment in them has the highest probability of paying off in the long run.

Now one last philosophical musing before I close. I have one last answer, and therefore, one last insight, this one a caveat. 
And the answer is: "But, but, and butt."

And the question is: "What is: the word that usually precedes why we can't do it, the word that should precede why we'll do it anyway, and what you have to get off of to make it happen?"

One of the premiere theories in psychology today is self-regulation theory. As faculty developers we can't wait around for someone to anoint us the saviors of higher education. We can't wait for the faculty to decide it's time to do something about teaching. We should be out in the front of the line, leading by example as well as by intellect. We should be the ones ready with the support when the opportunity arises. That is how we'll stay afloat in these seas of change; because when you're the only one who knows where the ship is headed, it is unlikely the others will throw you to the sharks.

\section{References}

Multiple references on post tenure review (1997). Academe, 83(3).

Angelo, T., \& Cross, K.P. (1993). Classroom assessment techniques. San Francisco: Jossey-Bass.

Boice, R. (1992). The new faculty member. San Francisco: Jossey-Bass.

Brookfield, S. (1995). Becoming a critically reflective teacher. San Francisco, CA: Jossey-Bass.

Chism, N. V., \& Warner, S. (Eds). (1987). Employment and education of teaching assistants: Institutional responsibilities and responses. Readings from a national conference. Columbus, $\mathrm{OH}$ : The Ohio State University Center for Teaching Excellence.

Halpern, D., \& Associates (1994). Changing college classrooms. San Francisco: JosseyBass.

Lewis, K. (Ed.). (1993). The TA experience: Preparing for multiple roles. Selected Readings from the 3rd National Conference on the Training and Employment of Graduate Teaching Assistants. Stillwater, OK: New Forums Press.

Nyquist, J., Wolff, D., \& Abbot, R. (Eds.). (1990). Preparing the professoriate of tomorrow to teach: Selected readings in TA training. Dubuque, IA: Kendall Hunt.

Richlin, L. (in press). Using CATs to shift the focus from teaching survival to student learning in beginning teachers. In T. Angelo (Ed.), Classroom assessment and research extended. New Directions for Teaching and Learning, No. 75. San Francisco: Jossey-Bass.

Sorcinelli, M., \& Austin, A. (Eds.) (1992). Developing new and junior faculty. New Directions for Teaching and Learning, No. 50. San Francisco: Jossey-Bass. 
Sullivan, T., Romo, R., Woodruff, P., \& Galinsky, K. (1997, January). Post tenure review. Panel discussion presented at the 1997 Experienced Faculty Conference. The University of Texas at Austin.

Svinicki, M., Hagen, A., \& Meyer, D. (1996). How research on learning strengthens instruction. In R. Menges \& M. E. Weimer (Eds.), Teaching on solid ground. San Francisco: Jossey-Bass.

Contact:

Marilla Svinicki

Center for Teaching Effectiveness

The University of Texas at Austin

Main 2200

Austin, Texas 78712-1111

(512) 232-1777

(512) 471-0596 FAX

msvinicki@mail.utexas.edu

Marilla Svinicki is the Director of the Center for Teaching Effectiveness at the University of Texas at Austin. She has published three books and many articles translating the principles of psychology into the practical concerns of classroom instruction. She served as the Executive Director of the Professional and Organizational Development Network in Higher Education. She serves as associate editor on the series New Directions for Teaching and Learning. She teaches graduate and undergraduate courses in the department of Educational Psychology at UT and intends to continue prodding the current and future generations of faculty developers to combine the best of research and practice for the enhancement of the field. 